\title{
PEMBERIAN REINFORCEMENT UNTUK MENINGKATKAN MOTIVASI, AKTIVITAS, DAN HASIL BELAJAR SISWA SMK PADA KOMPETENSI DASAR PEMELIHARAAN/SERVIS SISTEM KOPLING DAN KOMPONENNYA
}

\author{
Siti Nurvalah ${ }^{1}$, Ono Wiharna ${ }^{2}$, Yayat $^{3}$ \\ Departemen Pendidikan Teknik Mesin \\ Universitas Pendidikan Indonesia \\ J1. Dr. Setiabudhi No. 207 Bandung 40154 \\ sitinurvalah@yahoo.com
}

\begin{abstract}
ABSTRAK
Tujuan penelitian ini untuk meningkatkan motivasi, akrivitas dan hasil belajar peserta didik Penelitian ini menggunakan metode Penelitian Tindakan Kelas yang dilaksanakan dalam dua siklus pada semester genap tahun pelajaran 2015/2016 dan dilakukan di kelas XI TKR 5 SMK Negeri 2 Garut. Instrumen penelitian yang digunakan adalah lembar angket, lembar observasi pelaksanaan pembelajaran, lembar observasi aktivitas belajar, dan lembar tes berupa pre-test dan post test. Hasil penelitian menunjukan bahwa terjadi peningkatan pada motivasi belajar dalam kategori sangat kuat, terjadi peningkatan pada aktivitas belajar dalam kategori sangat tinggi, dan terjadi peningakatan hasil belajar peserta didik (aspek kognitif dalam kategori amat baik, aspek psikomotor dalam kategori amat baik, dan aspek afektif dalam kategori sangat positif). Pemberian reinforcement dapat meningkatkan motivasi, aktivitas, dan hasil belajar peserta didik, terjadi karena pemberian reinforcement yang bervariasi; pemberian reinforcement diberikan dengan segera tanpa menunda; mengatur jadwal penguatan dan memberikan reinforcement tepat pada waktunya; pemberian reinforcement diberikan tepat sasaran; dan menghindari pemberian reinforcement negatif.
\end{abstract}

Kata kunci: reinforcement, motivasi belajar, aktivitas dan hasil belajar, kopling, servis.

\section{PENDAHULUAN}

Sekolah Menengah Kejuruan (SMK) merupakan satu bentuk satuan jenjang pendidikan menengah atas yang menyelenggarakan pendidikan formal dengan kekhususan yang mempersiapkan lulusannya untuk siap bekerja. Pendidikan menengah kejuruan megutamakan penyiapan peserta didik untuk memasuki lapangan kerja serta mengembangkan sikap professional (Mulyasana, 2012). SMK memiliki peran strategis dalam mempersiapkan peserta didik yang potensial sebagai calon tenaga kerja, peserta didik yang disiapkan untuk memenuhi kebutuhan tenaga kerja di industri, melanjutkan ke jenjang selanjutnya, dan menciptakan lapangan pekerjaan secara profesional dan kompetitif (Fauziyah dan Jailani, 2014).

Pencapaian tujuan di atas dapat diwujudkan melalui proses pembelajaran yang melibatkan dua pelaku aktif, yakni: peran guru sebagai pencipta kondisi belajar peserta didik yang didesain secara sengaja, berkesinambungan, dan sistematis; peran peserta didik sebagai subjek pembelajaran, merupakan pihak yang menikmati kondisi belajar yang dicipatakan guru. Indikator keberhasilan proses pembelajaran dalam pencapaian tujuan di

\footnotetext{
${ }^{1}$ Mahasiswa Departemen Pendidikan Teknik Mesin FPTK UPI

${ }^{2}$ Dosen Departemen Pendidikan Teknik Mesin FPTK UPI

${ }^{3}$ Dosen Departemen Pendidikan Teknik Mesin FPTK UPI
} 
atas dapat dilihat melalui aktivitas belajar peserta didik di dalam kelas dan hasil belajar peserta didik setelah proses pembelajaran (Usman, 2006).

Hasil observasi awal peneliti di SMK Negeri 2 Garut, ditemukan bahwa pada kenyataannya hasil belajar dan aktivitas peserta didik pada kompetensi pemeliharaan/servis sistem kopling dan komponennya masih rendah. Secara lebih jelas, persentase hasil belajar peserta didik pada kompetensi pemeliharaan/servis sistem kopling dan komponennya. Hasil belajar peserta didik kelas XI TKR 5 SMK Negeri 2 Garut tahun ajaran 2015/2016 pada kompetensi dasar pemeliharaa sistem kopling dan komponennya tergolong masih rendah. Hal ini terlihat dengan masih banyaknya peserta didik sebanyak 15 orang atau 45,46\% yang belum mencapai KKM sebesar 70,00. Meskipun ada beberapa peserta didik yang mencapai KKM, tetapi belum sampai pada kompeten amat baik, dimana hanya 6 orang peserta didik $(18,18 \%)$ kategori baik, dan 12 orang peserta didik $(36,36 \%)$ yang dinyatakan dengan kategori cukup.

Rendahnya hasil belajar yang diperoleh peserta didik tidak terlepas dari beberapa hal yang terjadi di lapangan (Daryanto, 2012), diantaranya: (1) metode pembelajaran yang digunakan guru tidak bervariatif, sehingga peserta didik mudah merasa bosan; (2) proses pembelajaran yang berlangsung dilaksanakan dalam bentuk satu arah dan bersifat verbalisme, seperti aktivitas pembelajaran lebih banyak didominasi oleh guru dan semua tindakan telah ditentukan oleh guru; (3) guru kurang memberikan kesempatan bertanya pada peserta didik; (4) model pembelajaran yang biasa digunakan guru lebih menempatkan pendidik sebagai sumber primer.

Peserta didik kurang termotivasi dalam belajar, sedangkan motivasi memiliki peranan yang strategis dalam aktivitas belajar, karena dapat memberikan dorongan untuk melakukan aktivitas belajar (Syah, 2010). Akibat dari rendahnya motivasi belajar tersebut, berdasarkan pengamatan peneliti di lapangan, muncul fenomena-fenomena yang berkaitan dengan aktivitas belajar, seperti: (1) masih minimnya peserta didik yang berebut mengacungkan tangan untuk mengajukan pertanyaan; (2) masih rendahnya interaksi antara peserta didik dengan peserta didik lainnya, ataupun peserta didik dengan guru disaat berdiskusi; (3) kurangnya partisipasi dari peserta didik yang menjawab pertanyaan dari guru; (4) masih terdapat beberapa peserta didik yang kurang giat mengerjakan soal/kuis yang diberikan oleh guru; (5) terdapat banyak peserta didik yang tidak fokus dalam proses pembelajaran, contohnya: memainkan handphone, bersenda gurau, dan tidur; (6) masih didapati beberapa peserta didik yang mengumpulkan hasil belajar dengan cara mencontek. 
Peserta didik harus memiliki motivasi tinggi dalam proses pembelajaran, sejalan dengan pendapat (Ahmadi dan Supriyono, 2004) yang menjelaskan bahwa seseorang dikatakan memiliki motivasi tinggi, jika: peserta didik giat berusaha, tampak gigih dan tidak menyerah, giat membaca buku untuk memecahkan masalah dan untuk meningkatkan prestasinya. Salah satu upaya yang dapat dilakukan adalah dengan cara memberikan penguatan yang dapat meningkatkan motivasi dan aktifitas peserta didik selama proses pembelajaran. Penerapan pemberian penguatan dalam proses pembelajaran lebih dikenal dengan pemberian reinforcement.

Reinforcement (penguatan) merupakan hal yang dapat memberikan atau meningkatkan motivasi kepada peserta didik dalam memahami konsep-konsep yang dipelajarinya, guru dapat mempengaruhi motivasi belajar peserta didik. Penguatan atau reinforcement mempunyai peranan yang cukup besar dalam kegiatan belajar mengajar. Seorang peserta didik akan senang belajar setelah menerima penguatan dari gurunya. Apabila peserta didik memperoleh kepuasan setelah usahanya berhasil ia akan terdorong untuk maju lebih jauh dalam belajar, bentuk kepuasan itu dapat berupa rasa bangga dan percaya diri. Harapan lain dari pemberian reinforcement pada kompetensi pemeliharaan/servis sistem kopling dan komponennya di SMK Negeri 2 Garut adalah peserta didik dapat meningkatkan hasil belajar peserta didik guna bekal memenuhi tuntutan dunia kerja maupun untuk mengikuti pendidikan diperguruan tinggi.

\section{METODE PENELITIAN}

Metode yang digunakan dalam penelitian ini adalah penelitian tindakan kelas. Penelitian tindakan kelas diselenggarakan dengan berupaya menerapkan berbagai teknik, model, dan strategi secara efektif dan efisien didalam suatu proses pembelajaran. Bertujuan untuk lebih mendalami pemahaman terhadap tindakan yang dilakukan selama proses pembelajaran, serta untuk memperbaiki kualitas pembelajaran dikelas secara berkelanjutan. Prosedur penelitian tindakan kelas dilaksanakan melalui beberapa tahapan yang digambarkan dalam beberapa siklus, dalam satu siklus terdiri dari empat tahap. Keempat tahap tersebut adalah: (1) perencanaan (planning); (2) pelaksanaan tindakan (action); (3) observasi (observation); (4) refleksi (reflection). Kegiatan ini disebut satu siklus kegiatan pemecahan masalah. Penelitian Tindakan Kelas ini dilaksanakan di SMK Negeri 2 Garut. Subjek penelitian ini adalah peserta didik kelas XI Program Keahlian Teknik Kendaraan Ringan (TKR) 5 yang berjumlah 33 orang dengan jenis kelamin laki-laki. Teknik pengumpulan data yang digunakan berupa: lembar tes, lembar observasi, dan lembar 
angket. Data yang diperlukan dalam penelitian ini adalah data mengenai motivasi, aktivitas, dan hasil belajar peserta didik.

\section{HASIL PENELITIAN}

Pemberian tindakan pada proses pembelajaran siklus I dimulai dari perencanaan, dengan cara menentukan kelas, menentukan jumlah siklus, menyiapkan starategi pemberian reinforcement, menyusun RPP, menyiapkan sumber belajar, menyiapkan fasilitas dan sarana pendukung, menyusun format observasi, dan menetapkan kriteria keberhasilan. Pelaksanaan (a) tahap pembukaan: kelas masih belum kondusif. Sehingga guru harus mengkondisikan dan menegur peserta didik yang tidak memperhatikan guru. (b) tahap pre-test, karena terbiasa mengerjakan tugas dengan cara mencontek, hampir sebagian besar peserta didik ditemukan bertanya mengenai jawaban kepada temannya. (c) tahap pengisian angket: masih ditemukan peserta didik yang bertanya pada temannya dalam memilih alternatif jawaban mengenai motivasi belajar peserta didik sebelum menerima tindakan pemberian reinforcement pada proses pembelajaran. (d) tahap penyajian materi dan pemberian reinforcement. Setelah guru menyajikan materi dan memberikan tindakan pemberian reinforcement. Suasana kelas sudah mulai kondusif, dengan mulai terciptanya komunikasi dua arah antara peserta didik dengan guru. Hal ini ditunjukkan dengan sebagian besar peserta didik sudah antusias memperhatikan guru, dengan serius mendengarkan, serta mencatat. Tetapi masih belum terciptanya komunikasi dua arah antara peserta didik dengan peserta didik lainnya. Hal ini ditunjukkan dengan suasana diskusi kelas tidak terlihat hidup, karena hanya didominasi oleh peserta didik yang pandai dikelasnya. Pada tahap ini juga masih terdapat banyak peserta didik yang belum aktif bertanya ataupun menjawab pertanyaan. (e) Tahap post-test: setelah mendapat pengarahan dari guru mengenai larangan mencontek dan dampak negatif dari mencontek, hampir sebagian besar peserta didik sudah mengerjakan tugas secara mandiri dan sesuai dengan waktu yang telah ditentukan. (f) Tahap penutupan, guru memberikan hadiah kepada kelompok terbaik, peserta didik tampak senang, hal ini ditunjukan dengan peserta didik bertepuk tangan, mengucapkan kata "horee", dan mengucapkan terimakasih, dan berjanji akan lebih baik lagi di proses pembelajaran selanjutnya.

Pengamatan tahap ini berjalan bersamaan dengan saat pelaksanaan. Pengamatan dilakukan pada waktu tindakan sedang berjalan. Jadi keduanya berlangsung dalam waktu yang bersamaan. Hasil pengamatan selama pemberian tindakan menunjukkan bahwa sebagian besar peserta didik antusias mengikuti proses pembelajaran melalui pemberian 
reinforcement. Hal ini ditunjukkan dengan aktifnya peserta didik dalam bertanya, mampu mengeluarkan pendapat dalam berdiskusi, mengerjakan tugas secara mandiri dan sesuai dengan waktu yang telah ditentukan.

Refleksi, tahap ini merupakan tahap penutup satu rangkaian siklus 1. Pada tahap ini peneliti bersama guru mata pelajaran berkolaborasi untuk memperbaiki kekurangan pada pemberian tindakan siklus I. Perbaikan yang dilakukan berupa: berusaha lagi untuk bisa menarik perhatian peserta didik. Selalu memberikan motivasi dan semangat kepada peserta didik. Menitikberatkan peserta didik sebagai objek utama dalam proses pembelajaran. Guru harus memberikan pertanyaan umpan agar peserta didik dapat termotivasi untuk bertanya dan mengeluarkan pendapat. Guru menjelaskan kembali aturan dan teknis pembelajaran dengan pemberian reinforcement ini sampai peserta didik benar-benar paham. Guru memfokuskan pemberian reinforcement positif daripada pemberian reinforcement negative. Guru memberi pengarahan kepada peserta didik bagaimana menyikapi pelajaran dengan baik. Apabila ada hal yang tidak dimengerti oleh peserta didik, guru memberi arahan mengenai larangan dan bahaya mencontek. Lebih ketat dan tegas pada saat pelaksanaan tes, dan guru lebih memperhatikan alokasi waktu tiap-tiap tahapan pembelajaran.

Pada siklus I menunjukkan bahwa peserta didik masih belum memiliki semangat tinggi dalam mengikuti proses pembelajaran, hal ini dikarenakan guru masih belum maksimal memberikan reinforcement kepada peserta didik. Secara umum peserta didik yang belum mampu menunjukkan tanggung jawab secara individu dalam mengerjakan tugas, aktif dalam berdiskusi, bertanya dan mengemukakan pendapat disebabkan oleh guru yang belum maksimal memotivasi secara baik. menyatakan bahwa motivasi belajar merupakan faktor psikis yang berperan non intelektual, perannya yang khas adalah hal penumbuhan gairah, merasa senang, dan semangat untuk belajar (Sardiman, 2011).

Pemberian tindakan pada proses pembelajaran siklus II dimulai dari: (1) perencanaan, mempersipakan lembar angket, mempersiapkan lembar observasi peserta didik dan berlangsungnya proses pembelajaran, menyusun RPP, menyiapkan sumber belajar, menyiapkan fasilitas dan sarana pendukung, dan menetapkan kriteria keberhasilan; (2) pelaksanaan: (a) tahap pembukaan: suasana kelas sudah lebih teratur dibanding pada siklus sebelumnya. Hal ini ditandai peserta didik duduk sesuai dengan urutan nomor absen. Pakaian peserta didik sudah terlihat rapi dibanding dengan siklus sebelumnya. Sudah tidak terlihat peserta didik yang masih mengobrol dengan teman lainnya. (b) tahap pre-test: peserta didik sangat tertib menerima dan mengerjakan soal, dalam mengerjakan tugas 
sebagian besar peserta didik mengerjakan tugas secara mandiri dan sesuai dengan waktu yang telah ditentukan. Meskipun masih terdapat beberapa peserta didik yang bertanya kepada temannya. (c) tahap pengisian angket: peserta didik dengan tertib menerima lembar angket mengenai motivasi peserta didik. Sudah tidak ditemukan peserta didik yang bertanya kepada temannya untuk memilih alteratif jawaban. (d) tahap penyajian materi dan pemberian reinforcement, setelah mendapatkan tindakan pemberian reinforcement yang ke-2. Peserta didik sudah sangat tertib dalam proses pembelajaran. Hal ini ditunjukkan dengan peserta didik dengan seksama memperhatikan, mencatat, antusias mengacungkan tangan ketika guru bertanya. Antusias untuk mengeluarkan pendapat tanpa diperintahkan guru. Peserta didik lebih kritis bertanya bila ada materi yang belum dimengerti. Pada saat berdiskusi sudah terlihat hidup, karena tidak hanya didominasi oleh peserta didik yang pandai saja. (e) tahap post-test: dengan teratur peserta didik menerima lembar post-test. Peserta didik mengerjakan pos-test secara serius, dan sudah tidak terlihat peserta didik mengerjakan tugas dengan cara mencontek pekerjaan teman lainnya. (f) tahap penutupan: peserta didik berlomba-lomba mengacungkan tangan untuk menyimpulkan materi yang telah diberikan guru. Kemudian guru memberikan hadih kepada kelompok terbaik pada proses pembelajaran ke-2. Peserta didik terlihat bahagia, merasa bangga dengan hasil yang diperoleh.

Pengamatan, penelitian pada siklus II peserta didik lebih siap dalam mengikuti proses pembelajaran. Sebelumnya guru telah memberikan intruksi kepada peserta didik mengenai materi yang akan dipelajari pada siklus II. Memberikan kesempatan lebih kepada peserta didik untuk menjadi objek dalam proses pembelajaran. Meminta peserta didik untuk bebas memberikan pendapat dan sanggahan.

Refleksi, suasana pembelajaran sudah sesuai dengan tujuan pemberian reinforcement. Secara umum tahapan pemberian reinforcement pada proses pembelajaran pada kompetensi pemeliharaan/servis sistem kopling dan komponennya sudah terlaksana dengan baik. Sudah mampu meningkatkan motivasi, aktivitas, dan hasil belajar peserta didik. Hal ini ditunjukan dengan: peserta didik sudah tidak malu mengacungkan tangan untuk bertanya dan mengemukakan pendapat. Rata-rata motivasi belajar peserta didik pada siklus II sebanyak 90,98\%. Peserta didik termasuk dalam kategori sangat kuat. Rata-rata aktivitas belajar peserta didik pada siklus II sebanyak 91,21\% peserta didik termasuk dalam kategori sangat tinggi. Rata-rata hasil belajar peserta didik pada aspek kognitif sebesar 90,75. Rata-rata hasil belajar peserta didik pada aspek psikomotor sebesar 92,15. Rata-rata hasil belajar peserta didik pada aspek afektif sebesar 95,57. 


\section{PEMBAHASAN}

Hasil penelitian menunjukkan adanya peningkatan yang signifikan pada motivasi belajar peserta didik pada kompetensi pemeliharaan/servis sistem kopling dan komponennya dengan memberikan reinforcement pada proses pembelajarannya (Santrock, 2007). Hal ini dapat dilihat pada hasil perolehan quisioner di siklus I dan siklus II. Ratarata persentase peningkatan motivasi belajar peserta didik pada siklus I sebesar $71,5 \%$ dan siklus II sebesar 90,98\%. Persentase peningkatan motivasi belajar peserta didik pada kompetensi pemeliharaan/servis sistem kopling dan komponennya dengan memberikan reinforcement pada proses pembelajarannya dari siklus I ke siklus II sebesar 19,4\%.

Secara keseluruhan pemberian tindakan reinforcement pada proses pembelajaran siklus ke II menunjukkan bahwa pemberian reinforcement mampu menghidupkan dan membangkitkan motivasi belajar peserta didik sehingga dapat meningkatkan aktivitas belajar pula (Sudjana, 2010). Pemberian reinforcement efektif untuk meningkatkan rasa percaya diri peserta didik dan merubah tingkah laku peserta didik ke arah yang lebih positif (Asri, 2014). Pemberian reinforcement efektif dalam membangun kesadaran peserta didik untuk mengubah prilaku ke arah yang lebih positif (Indayani, 2014). Reinforcement bertujuan untuk meningkatkan perhatian peserta didik dan membangkitkan motivasi peserta didik (Winataputra, 2004). Melalui pemberian penguatan guru terhadap prilaku belajar peserta didik. Sehingga peserta didik merasa diperhatikan oleh gurunya. Peserta didik akan semakin meningkat seiring dengan perhatian melalui respon yang diberikan kepada peserta didik. Apabila perhatian peserta didik ke arah yang lebih baik, maka dengan sendirinya motivasi belajar peserta didik akan semakin baik pula.

Motivasi belajar peserta didik pada siklus II meningkat dibandingkan dengan siklus pertama. Peningkatan motivasi belajar peserta didik pada siklus II dapat terjadi dikarenakan beberapa hal: pemberian reinforcement yang bervariasi dan tepat waktu, sehingga mampu mendorong peserta didik untuk meningkatkan motivasi intrinsik pada diri peserta didik; dan pemberian reinforcement yang digunakan lebih menitikberatkan pada jenis reinforcement positif, sehingga peserta didik tidak merasa tertekan selama proses pembelajaran berlangsung (Usman dan Setiawati, 2001).

Pujian dan hadiah adalah bentuk reinforcement positif dan sekaligus motivasi yang baik (Sardiman, 2011). Oleh karena itu, agara pujian dan hadiah itu merupakan motivasi, pemberiannya harus tepat waktu. Dengan pujian dan hadiah yang tepat waktu akan memupuk suasana yang menyenangkan dan mempertinggi gairah belajar serta sekaligus membangkitkan harga diri. 
Hasil penelitian menunjukkan adanya peningkatan aktivitas belajar peserta didik pada kompetensi pemeliharaan/servis sistem kopling dan komponennya. peningkatan aktivitas belajar peserta didik pada kompetensi pemeliharaan/servis sistem kopling dan komponennya dapat dilihat pada hasil observasi di siklus I dan II. Aktivitas belajar peserta didik meningkat setelah memberikan reinforcement pada proses pembelajarannya. Peningkatan mengenai rata-rata persentase aktivitas belajar peserta didik pada siklus I sebesar $67,57 \%$ dan siklus II sebesar 91,21\%. Persentase peningkatan aktivitas belajar peserta didik dengan memberikan reinforcement pada proses pembelajarannya dari siklus I ke siklus II sebesar 23,64\%.

Pemberian reinforcement ini telah berhasil memperbaiki aktivitas belajar peserta didik, peningkatan aktivitas belajar peserta didik ini terkait dengan karakteristik reinforcement yang mampu membangkitkan motivasi dan dengan motivasi mampu meningkatkan aktivitas belajar peserta didik. Reinforcement sebagai sebuah konsekuen yang menguatkan tingkah laku atau frekuensi tingkah laku (Baharuddin, 2008). Peningkatan aktivitas belajar peserta didik pada siklus II dapat terjadi dikarenakan beberapa hal: (1) adanya keinginan peserta didik untuk memelihara kelas agar tetap kondusif; (2) keterbukaan peserta didik menyampaikan apa yang mereka pikirkan; (3) adanya keinginan peserta didik menjadikan kelas lebih demokratis; (4) adanya keterlibatan peserta didik berperan aktif dalam melakukan perbuatan ke arah lebih baik. Reinforcement bertujuan untuk memelihara iklim kelas yang kondusif, suasana kelas yang menyenangkan, aman, dan dinamis akan mendorong proses pembelajaran lebih optimal. Melalui penguatan yang dilakukan oleh guru (Sanjaya, 2006), suasana kelas akan lebih demokratis, sehingga peserta didik akan lebih bebas untuk mengemukakan pendapat, berbuat, mencoba dan melakukan perbuatan-perbuatan belajar lainnya (tentunya ke arah prilaku yang positif).

Hasil penelitian menunjukkan adanya peningkatan hasil belajar ranah kognitif pada pemeliharaan/servis sistem kopling dan komponennya (Ling dan Catling, 2012). Peningkatan hasil belajar peserta didik pada pemeliharaan/servis sistem kopling dan komponennya dapat dilihat dari perbandingan rata-rata nilai pre-test dan post-test pada siklus I dengan rata-rata nilai pre-test dan post-test pada siklus II dan perbandingan ratarata $N$-Gain pada siklus I dengan siklus II. Perbandingan nilai rata-rata nilai pre-test dan post-test pada siklus I dan II

Perbandingan rata-rata nilai pre-test pada siklus I sebesar 42,57. Pada siklus II meningkat menjadi 65,45, dan mengalami peningkatan sebesar 22,8. Rata-rata nilai posttest pada siklus I sebesar 72,27, pada siklus II meningkat menjadi 90,75, dan mengalami 
peningkatan sebesar 18,48 . Peningkatan hasil belajar peserta didik juga dapat dilihat dari perbandingan rata-rata $N$-Gain pada siklus I dengan rata-rata $N$-Gain pada siklus II. Adapun perbandingan rata-rata $N$-Gain pada siklus I dan II, rata-rata $N$-Gain pada siklus I sebesar 0,54, dan mengalami peningkatan sebesar 0,22 pasa siklus II menjadi 0,76.

Peningkatan hasil belajar peserta didik ranah psikomotor dapat dilihat dari perbandingan rata-rata nilai psikomotor siklus I dan rata-rata nilai psikomotor siklus II. Perbandingan rata-rata nilai psikomotor siklus I siklus II, hasil belajar ranah psikomor, perbandingan rata-rata nilai psikomotor pada siklus I sebesar 74,50 dan pada siklus II menjadi 92,15. Sehingga terjadi peningkatan sebesar 17,55.

Peningkatan hasil belajar peserta didik ranah afektif dapat dilihat dari perbandingan rata-rata nilai afektif siklus I dan siklus II. Perbandingan rata-rata nilai psikomotor siklus I dan rata-rata nilai psikomotor siklus II, hasil belajar ranah afektif, perbandingan rata-rata nilai afektif pada siklus I sebesar 79,74 dan pada siklus II menjadi 95,57, hal ini menunjukkan terjadi peningkatan sebesar 15,83.

Pemberian reinforcement dapat meningkatkan hasil belajar peserta didik (kognitif, afektif, dan psikomotor). Peningkatan hasil belajar ini merupakan dampak positif dari peningkatan motivasi dan aktivitas belajar peserta didik setelah dilakukan tindakan pemberian reinforcement selama proses pembelajaran (Apriansyah, 2013). Peserta didik yang memiliki motivasi belajar dan sikap sangat positif terhadap pelajaran, akan merasa senang mempelajari mata pelajaran tersebut, sehingga dapat mencapai hasil pembelajaran yang optimal. Adanya usaha yang tekun dan terutama didasari adanya motivasi, maka seseorang yang belajar itu akan dapat melahirkan prestasi yang baik (Hamalik, 2011).

\section{KESIMPULAN}

Kesimpulan dari penelitian ini adalah pemberian reinforcement dalam proses pembelajaran dapat meningkatkan motivasi, aktivitas, dan hasil belajar peserta didik. Pemberian reinforcement dapat meningkatkan motivasi, aktivitas, dan hasil belajar peserta didik, terjadi karena pemberian reinforcement yang bervariasi; diberikan dengan segera tanpa menunda; mengatur jadwal penguatan dan memberikan reinforcement tepat pada waktunya; diberikan tepat sasaran; dan menghindari pemberian reinforcement negatif.

\section{DAFTAR PUSTAKA}

Ahmadi, A. dan Supriono, W. (2004). Psikologi Belajar (Edisi Revisi). Jakarta:Rineka Cipta 
Apriansyah, A. dkk. (2013). Materi Seminar Pendidikan: Peran Guru untuk Meningkatkan Motivasi Belajar Siswa. Kuningan: Universitas Kuningan

Asri, N.L. (2014). Efektivitas Konseling Behavioral dengan Teknik Positive Reinforcement untuk Meningkatkan Rasa Percaya Diri dalam Belajar pada Siswa Kelas VIII SMP Negeri 2 Singaraja Tahun Pelajaran 2013/2014. E-jurnal Undiksha Jurusan Bimbingan Konseling. II (I)

Baharrudin. (2008). Pendidikan dan Psikologi Perkembangan. Yogyakarta: Ar-ruzz

Daryanto. (2012). Evaluasi Pendidikan. Jakarta: Rineka Cipta

Fauziyah, L. \& Jailani. (2014). Pengembangan Perangkat Pembelajaran Matematika yang Menunjang Pendidikan Karakter Siswa Kelas IV Sekolah Dasar. Jurnal Prima Edukasia. II (II)

Hamalik, O. (2011). Proses Belajar Mengajar. Jakarta: Bumi Aksara

Indayani, A. (2014). Penerapan KOnseling Behavioral dengan Tekik Penguatan Positif sebagai Upaya untuk Meminimalisi Perilaku Membolos pada Siswa kelas X.1 SMA Negeri 1 Sawan Tahun Ajaran 2013/2014. E-jurnal Undiksha Jurusan Bimbingan Konseling. II (I)

Ling, J. dan Catling, J. (2012). Psikologi Kognitif. Jakarta: Gelora Aksara Pratama

Mulyasana, D. (2012). Pendidikan bermutu dan berdaya saing. Bandung: Remaja Rosdakarya

Sanjaya, W. (2006). Strategi pembelajaran. Jakarta: Pranada Media Group.

Santrock, J. W. (2007). Psikologi pendidikan (Edisi Kedua Terjemahan). Jakarta: Prenada Media Group

Sardiman. (2011). Interaksi \& Motivasi Belajar Mengajar. Jakarta: Raja Grafindo Persada

Sudjana, N. (2010). Penilaian Hasil Proses Belajar Mengajar. Bandung: Remaja Rosdakarya

Syah, M. (2010). Psikologi Pendidikan dengan Pendekatan Baru. Bandung: Remaja Rosdakarya Offset

Usman dan Setiawati. (2001). Upaya Optimalisasi Kegiatan Belajar Mengajar. Bandung: Remaja Rosdakarya

Usman, M.U. (2006). Menjadi Guru Profesional. Bandung: PT. Remaja Rosdakarya

Winataputra, U. S. (2004). Belajar dan Pembelajaran. Jakarta: Departemen Pendidikan Nasional. 